\title{
Cephe Tasarımında Sembolizm ve İsmailiye Sarayı Cephesindeki Değişim Süreci
}

\author{
Symbolism in Facade Design and The Process of Change in The Facade of \\ Ismailliyya Palace \\ Didem ERTEN BİLGİÇ" \\ Zeyneb TAHIRLí ${ }^{* *}$
}

\begin{abstract}
$\ddot{O} z$
Sembolizm hayatın bütün alanlarında, özellikle mimaride sıkça kullanılmaktadır. Çalışmada bir yapının en önemli bölümlerinden olan cephe tasarımı üzerinde sembolizm kavramının kullanımı anlatılmaktadır. Azerbaycan'ın başkenti Bakü'de bulunan önemli yapılardan İsmailiye Sarayı'nın eski ve restorasyon sonrası yeni cephesinin değişim sürecindeki siyasal ve dini etkiler ile sembolizm arasındaki ilişki incelenmektedir. Çalışmanın amacı, İsmailiye Sarayı üzerinden cephe tasarımında uygulanmış sembolizmin izlerini örnekler göstererek tahlil etmektir. Bu bağlamda sembolizmin cephe tasarımındaki yansımalarının mimari tasarım üzerindeki etkisinin örneklerde gösterilmesi hedeflenmektedir. 1908-1913 yıllarında Musa Nağıyev tarafindan yapılmış olan bu saray, çeşitli zamanlarda tarihi olaylara şahitlik etmiştir. 1918 Mart olayları sırasında Ermeniler tarafindan yağmalanan ve ateşe verilen bina neredeyse tamamen yok edilmiştir. Birkaç sene sonra SSCB binayı yıkma kararı alsa da yerel halkın itirazı nedeniyle binanın restorasyonuna başlanılmıştır. Binayı restore eden Sovyet iktidarı her zaman olduğu gibi yine bu sarayda da kendi izlerini bırakarak değiş̧iklikler yapmıştır. Yapılan çalı̧̧mada yapının yangından önceki durumuyla yangından sonraki durumu karşılaştırılarak nicel bilimsel araştırma yöntemlerinden nedensel-karşılaş̧ırma yöntemi kullanılarak incelenmiş̧ir. $\mathrm{Bu}$ makale, Azerbaycan mimarisinde önemli yeri olan İsmailiye Binası'nın cephesinin siyasal, dini etkenler ile tarihsel süreçte nasıl değiştiğini karşılaştırmalı çizim ve resimlerle ortaya koyması açısından önem arz etmektedir. Çalışmanın sonucunda mimaride sembolizmin ne kadar etkili olduğunu görmek mümkündür.
\end{abstract}

Anahtar Kelimeler: Saray Mimarisi, Azerbaycan Mimarisi, Kültür, SSCB, Sembolizm.

\begin{abstract}
Symbolism, used in all areas of life, is preeminent in architecture. This study elucidates the use of symbolism in facade design, which is one of the most important parts of a building. The correlation between the political and religious influences along with symbolism in the pre and post-restoration of the Ismailiye Palace's facade, amongst the significant structures in Baku, the capital of Azerbaijan, has been examined. The purpose of the study is to analyze the traces of symbolism present in the facade design of the Ismailiye Palace by providing exemplars. In this regard, the reflections of symbolism in facade design on the architectural design through exemplars have been demonstrated. Ismailliyya Palace, which was built by Musa Nagiyev between 1908-1913, has witnessed various historical events. The building, which was looted and set on fire by the Armenians during the events of March 1918, was almost destroyed. Although the USSR decided to demolish the building a few years later, restoration was commenced due to the objection of locals. The Soviet government has restored the building, however made changes in the palace by leaving their trace. In the study, the situation of the building before the fire was compared with its situation after the fire and was examined using the quantitative comparison method, a quantitative-scientific research method. This article regards how the facade of the Ismailiye Building has changed during history on political and religious aspects, with comparative drawings and pictures. Consequently, it is possible to see how effective symbolism is in architecture.
\end{abstract}

Keywords: Palace Architecture, Azerbaijani Architecture, Culture, USSR, Symbolism.

\section{Giriş}

19. yüzyılın sonlarında ortaya çıkmış olan sembolizme gözle görülemeyen düşünce ve inançların somutlaşmış hali denilebilir. Bütün insanlık tarihi boyunca var olan semboller farklı alanlarda farklı amaçlar için kullanılmıştır. Bir düşüncenin ya da bir felsefenin, idari erkin, kültürün, inanışın değerlerinin görselleştirilmiş hali olarak da tanımlanabilir. Resim, edebiyat, sanat gibi bir çok alanlarda olduğu gibi mimarlıkta da sembolizme yer verilmiştir. Sembolizm mimarlıkta plan şemasının oluşturulmasından dekorasyona, iç mimari tasarımdan cephe tasarımına kadar binyıllardır kullanılagelmiştir. Yapının cephesinin izleyicisi çok

\footnotetext{
*Doç. Dr., Kocaeli Üniversitesi, Mimarlık ve Tasarım Fakültesi, İç Mimarlık Bölümü, didemerten@gmail.com Kocaeli Üniversitesi, Sosyal Bilimler Enstitüsü, zeynebtahirli93@gmail.com
} 
olduğu için estetik açıdan daha vurgulayıcı olması tercih edilirken tüm ideolojik, kültürel, siyasi mesajların da verilebildiği bir reklam panosu gibi değerlendirilebilir. Özellikle yapının dış imajı bakımından önemli bir değere sahip olan cephe tasarımında da sembolizmin tasarıma hakim olması durumuna pek çok mimari yapıtta rastlanmaktadır. Bunlardan biri de Azerbaycan Cumhuriyet tarihinde önemli olaylara şahitlik etmiş İsmailiye Sarayı'dır. Yapı, Bakü'nün ekonomik açıdan önde gelen liderlerinden Ağa Musa Nağıyev tarafından genç yaşta vefat eden oğlu İsmailin anısına Müslüman Hayır Cemiyeti (kurumu) için inşa edilmiştir. Polonyalı mimar Jozef Plosko tarafindan 1908-1913 yıllarında yapılan saray 23 Ocak 1945'den 1991'e kadar Azerbaycan SSCB Ulusal Bilimler Akademisi olarak kullanılmıştır. 1991 yılından (bağımsızlıktan sonra) günümüze kadar ise Azerbaycan Ulusal Bilimler Akademisi Başkanlık Binası olarak faaliyet göstermektedir.

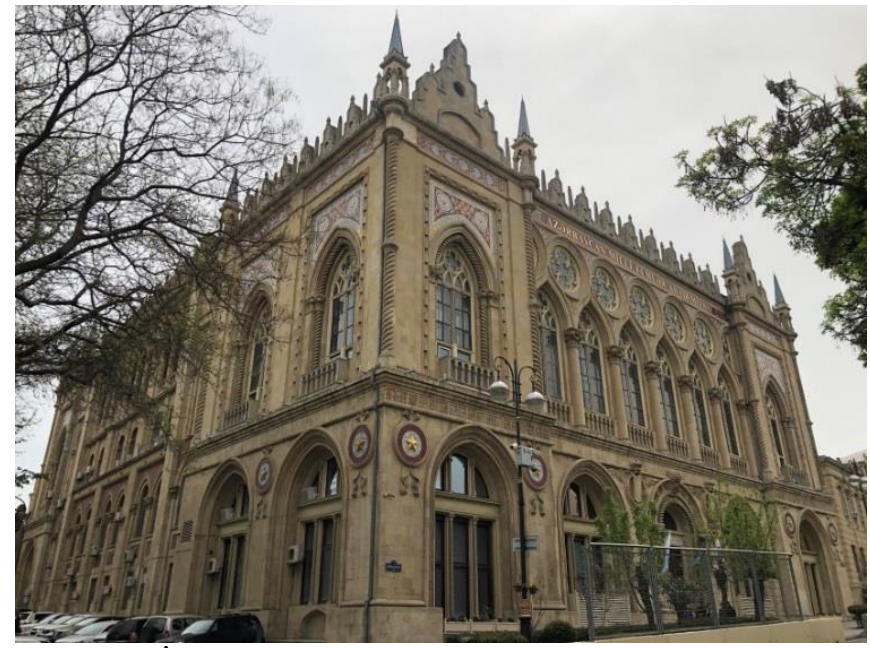

Şekil 1: İsmailiye Sarayı (2. Yazar fotoğraf arşivi, 2021).

1918 Mart olayları zamanı Bakü'nün kontrolünü ele geçiren Ermeniler, işgal ettikleri yerlerde sadece şehir nüfusuna değil, kültürel değerler taşıyan binalarına da zarar vermeye çalışmışlardır. O dönemde en çok hasar gören yapılardan biri İsmailiye Sarayı'dır. Saray önce yağmalanmış, sonra ateşe verilmiştir. Sarayda çıkan yangın sırasında binaya verilen hasarın yanı sıra sarayın kendisi de dahil olmak üzere sarayda faaliyet gösteren kurumların arşivleri de yanarak yok edilmiştir. Bakü'nün kurtuluşundan sonra Kafkas İslam Ordusu İsmailiye Sarayı'nın önünde onursal geçit töreni düzenlemiştir. Azerbaycan'da Sovyet iktidarı kurulduktan sonra sarayın yararsız halde olduğu gerekçesiyle yıkılmasına karar verilmiş ancak yerel halkın itirazı nedeniyle 1923 yılında binanın restorasyonuna başlanılmıştır. Bina, 1922-1923 yıllarında Alexander Dubov'un katılımıyla restore edilmiş ve bir süre Türk Kültür Sarayı adını almıştır. Binanın restorasyonu sırasında, İsmailiye başlığı yerine "Намят Нагиевым" (Nağıyev anısına) yazılmıştır (URL-1, 2021). 1923'den günümüze kadar herhangi bir onarım ya da değişiklik görmemiş yapıda 2020 yılında hasarların giderilmesine yönelik restorasyon yapılmıştır. İdeolojilerin ve siyasi yapılanmaların bu derece etkin olduğu bu coğrafyada da, yapılarda sembolizmin kullanılması kaçınılmaz bir durumdur.

Çalışmanın ilerleyen bölümlerinde binanın 1913 yılında yapılmış orjinal cephe tasarımı ile restorasyon sonrasındaki cephe tasarımında yer verilmiş olan sembollerin anlamsal karşılıklarına ilişkin irdelemeler yapılacaktır.

Yapılan çalışmada Bakü'nün merkezinde yerleşen ve çeşitli zamanlarda tarihi olaylara şahitlik etmiş İsmailiye Sarayı'nın öncelikle tarihsel süreci tarihi kaynaklarla incelenecektir. Çalışmanın sonraki aşamasında nicel bilimsel araştırma yöntemlerinden nedenselkarşılaştırmalı yöntem kullanılacaktır. 
Yapının sonuçta geçirmiş olduğu restorasyon sürecinin yapının orjinal mimari özelliklerini ne derece koruduğu belgelenmiş olacaktır.

\section{Sembolizm ve Mimari Tasarım}

Sembol görülemeyen veya algılanamayan bir şeyi, resim, motif, sayı, renk, işaret veya şekil olarak ortaya çıkarabilen bir unsurdur. Yunanca "Symbolum" sözcügünden alınan ve teknik bir terim olan sembol sözcüğü, anı parçası anlamına gelmektedir. Hislerle algılanamayan şeyleri, algılanabilir bir duruma getiren somut şeyler veya simgelerdir. Başka bir ifade ile insan düşüncesinde görünmeyen bazı şeyleri, onunla ilişkisi nispetinde görülebilir bir şekilde tasvir eden şeylere sembol denir. Yunanlar ise bu sözcüğü Mesih'e inanç fikirlerini bir araya getirmek için; yani gizemli ritüellerde inancın alameti olarak kullanmaktaydılar. (Dianat, 2015, s. 3).

Türkçe'de "alamet, nişane, mühür, rütbe veya makam işareti, teminat, vergi tahsili, iane ve toplantı" gibi anlamlar veren Sembol kelimesi "remiz" kelimesiyle ifade edilebilir. Remiz ise "temsili bir karş1lik olarak başka bir şeyi anlatan, somut olarak karşımızda olmayan veya idrak edilmesi imkansız olan herhangi bir şeyi, zihne taşımada kullanılan somut bir işaret” şeklinde tanımlanabilir (Aydeniz, 2011, s. 76).

Sembolizm; 19. yüzyılın sonlarında, gerçekçilik akımının etkisiyle oluşan parnasizm hareketine tepki olarak Fransa'da doğan bir sanat akımı olup, önce şiirde, sonra edebiyatın diğer dallarında ve diğer sanatlarda ortaya çıkmıştır. Fransız şairi Jean Moreas, 1886 'da Le Figaro gazetesinde yayımladığı "sembolizmin manifestosu" yazısıyla akımın adını ve esaslarını ilk defa ortaya koyarak sembolizmi "fikri algılanabilir bir biçimde giydirmek" olarak tanımlamıştır (Alodalı, 2015, s. 14). Soyut birer olgu olan duygu, düşünce, ruhsal durum ve inanışların somut bir şekilde iletilmesi ve canlandırılması sembolizmin ana hedefidir. Bu açıdan bakıldığında sembolizmin katı akılcılık ve bilime atfedilen önemin ve materyalizmin yükseldiği, manevi değerlerin gittikçe önemini yitirdiği 19. yy. Avrupasında ortaya çıkması, hiç de şaşırtıcı olmamıştır . Akım olarak ele alındığında yukarıdaki şekilde bir kronolojiye oturtuluyorsa da, sembolizmin tarz olarak kullanımı insanlık tarihi kadar eskiye dayanmaktadır (Alodal1, 2015, s. 15).

Örneğin, Türklerin eski inançlarından olan Gök Tanrı inancında insanlar güneş, ay, ateş ve suyu Tanrının kudretinin sembolleri olarak kabul etmiş ve Gök’e dua ederek enerji aldıklarını düşünmekteydiler.

Semboller insanlık tarihi boyunca, günlük hayattan büyük savaşlara kadar pek çok bilgi, mağara resimleri, totemler, heykellerde kullanılarak günümüze kadar aktarıla gelmişlerdir (Alodal1, 2015, s. 15).

Gelecek zamana bir nişane bırakabilmek düşüncesiyle yapıldıkları düşünülen semboller, insanlar arasında birçok farklı çağrışımlar uyandırmış ve işaret etmekte oldukları gerçeğin kalıcılıklarını sağlamışlardır.

İnşa edilmiş bütün yapıların daha uzun ömürlü olması, tesir alanının ve süresinin genişliği, anlatım biçimlerinin zenginlikleri ve geniş kitlelere ulaşabilirliğinin olması gibi birçok sebeplerden dolayı mimarlık, diğer tasarım ve sanat disiplinlerine bakıldığında daha çok etkiye sahiptir. İlk çağlardan günümüze kadar düşüncelerin mimari eserler üzerinden iletilmiş olduğu görülmektedir (Alodalı, 2015, s. 43).

Bir mimari yapının özellikle biçimini etkileyen fiziksel ve kültürel faktörler çoğu zaman doğrudan görülüp algılanabilmektedir. $\mathrm{Bu}$ çalışmada mimarinin biçimlenişini doğrudan etkileyen etmenlerden biri olan semboller ele alınmaktadır.

Aslında form aracılığıyla insanlara aktarılan bir düşünce olan sembolün mimarlık alanında en önemli öğelerinden biri de süslemelerdir. Cephe tasarımında sıkça uygulanan süslemeler insanları psikolojik, dolayısıyla da fiziksel olarak etkilemektedir.

Belli bir şeklin anlamı her zaman aynı değildir. Örneğin, üçgen formu şekil olarak geometrik, ancak sembolik anlamda değerlendirildiğinde, üçgen üç sayısını temsil ettiği için birçok üçlü gruplar tarafından sembol olarak kullanılmıştır. Üç bölümden oluşan üçgenler ve 
benzerleri geçmiş, şimdiki zaman ve gelecek, ruh, zihin, beden gibi kavramları anlatmak için kullanılmıştır.

İlk mimari yapı örneklerinde bile yapılan süslemelerin amacı sadece estetiksel açıdan değil, aynı zamanda yapının formunu belirleyen ana fikrini yansıtabilmektir.

Örneğin, kubbeler İslam mimarisinde kullanıldığı kadar sivil mimaride de sıkça kullanılmıştır. Kubbelerin genel olarak fonksiyonları şöyle özetlenebilir:

Mekanda akustiği sağlar,

Küçük bir göğü (mikrokozmoz) simgeler,

Yapıya içten ve diştan görkemli bir görünüm verir,

İ̧ mekanı genişletir,

Sert ve köşeli biçimlerin rahatsız edici olması, küresel ve dairesel biçimlerin ise mekana başka bir rahatlık ve genişlik vermesi sebebinden kubbeler insanın ruhsal hali üzerinde daha olumlu bir etki yaratmaktadır (Dianat, 2015, s. 33).

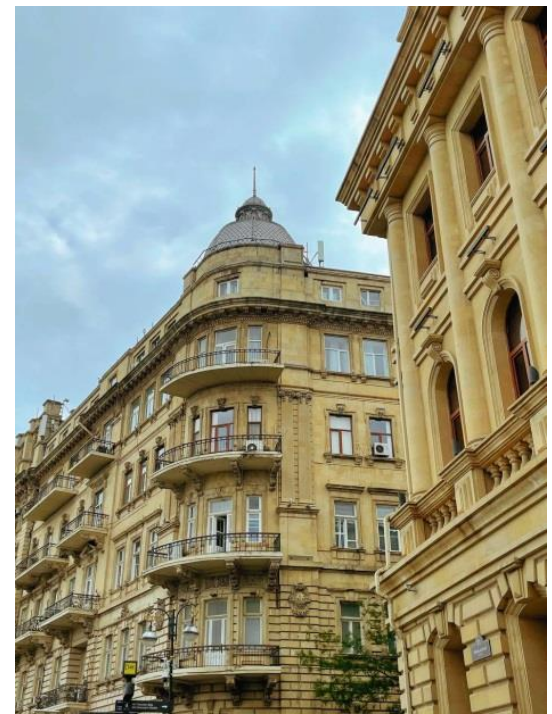

Şekil 2: Kubbe öğesinin kullanılmış olduğu, Bakü’de inşası 1917 yılında tamamlanmış, binada bulunan evlerin kiraya verilerek gelir elde edilmesi amacıyla yapılmış Mirzabeyov’un binası (Hasanlı, 2021).

Yapı cephelerinde kullanılan süslemeler, dönemin mimari anlayışını ortaya koymuş olsa da, çoğu zaman dekoratif tesirlerin ötesinde anlamlar da taşımıştır. Örneğin Yunan tapınakları üzerindeki kabartma ve heykeller asla günümüzde kullanılan dekorasyon anlamında kullanılmamış, bu süslemelerin amacı belli bir hikayeyi anlatmak, mabedi tapınılan Tanrıça'nın simgesi yapmak veya tapınağın inşa dönemindeki hikayesini anlatmak olmuştur. $\mathrm{Bu}$ süslemeler, yapının strüktürel öğelerinin anlatımından aciz olduğu şeyleri anlatmıştır. Yapının kolon ve kirişleri nasıl binanın bir parçasıysa bu süslemeler de binanın bir parçası olmuştur. $\mathrm{Bu}$ süslemeleri taklit ederek dünyanın başka bir noktasındaki bir yapıda uygulanması hiçbir anlam ifade etmemektedir. Mimari sırf bir yapı için tasarlanan cephe tasarımı değil, toplumun asıl değerlerini anlatmak için kullanılan bir yöntemdir (Dianat, 2015, s. 120).

\section{İsmailiye Sarayı'nın Azerbaycan Mimarisindeki Yeri}

İsmailiye Sarayı, 1907 yılında döneminin ekonomik açıdan önde gelen liderlerinden olan ve Sovyet egemenliği, Azerbaycan'da 98 bina yaptıran, Azerbaycan için faydalı işler gören Ağa Musa Nağıyev tarafından yaptırılmıştır. Dönemin çaresiz hastalığı sayılan verem nedeniyle genç yaşta vefat eden oğlu İsmail'in anısına bina yaptıran Ağa Musa Nağıyev bu binayı Polonyalı mimar Jozef Plosko'ya Müslüman Hayır Cemiyeti kullanımına dair 
yaptırmıștır. Yapımı 1913 yılında tamamlanmıș ve mimari özelliklerinden dolayı șehrin en görkemli yapısı olarak bilinen İsmailiye Sarayı hakkında Azerbaycan Halk Cumhuriyeti kurucusu Mehemmed Emin Resulzade Türkiye'de yayınlamış olduğu "Azerbaycan Cumhuriyeti" kitabında şöyle demiştir: "Belki de böyle bir amaç için inşa edilen binaların ihtişamı açısından bu bina İslam dünyasında bir ilktir." (URL-1, 2021).

Bakü'de Gotik tarzda yapılmış ilk bina olan İsmailiye Sarayı'nın yerinde başlangıçta “Cuma Cami'sinin yapımı düşünülmekteymiş, ancak bir sonraki caddede lüks bir Alexander Nevsky Katedrali yapılmakta olması sebebiyle bu teklif Çarlık yetkilileri tarafından reddedilmiş ve caminin yerinde İsmailiye Sarayı'nın yapımına izin verilmiştir (Fetullayev-Figarov, 2013, s. 24).

İnşası 1913 yılında tamamlanmış olan binaya ilk taşınan Müslüman Hayır Cemiyeti'nin yönetimi olmuştur. Ardından Bakü'de var olan bütün eğitim cemiyetleri binaya taşınmıştır. Ancak bir yıl sonra Birinci Dünya Savaşının başlaması nedeniyle bina hastane olarak kullanılmaya başlamıştır.

1918 Mart soykırımı ile Ermeniler binaya zarar vermişlerdir. Şöyle ki ilk başta yağmalanan binanın aynı zamanda ön cephesinde bulunan yaklaşık 6 kilogram ağırlıkta altından yapılmış olan İsmailiye yazısı Ermeniler tarafından çalınmış, binada bulunan bütün arşivler yakılmış ve yok olmuştur (URL-2, 2021).

1920 yılında Azerbaycan'da Sovyet Sosyalist Cumhuriyetler Birliği'nin kurulmasından sonra İsmailiye Sarayı'nın yıkımına karar verilmiş, ancak yerel halkın binanın önüne toplanarak itiraz etmesi nedeniyle restore edilmesine başlanılmıştır. Binanın restorasyon işleri için Ermeni mimar Vartan Sarkisov görevlendirilmiştir. Restorasyon sırasında binanın genel planında değişiklik yapılmasa da, cephede bazı değişiklikler yapılmıştır. Eldeki yazılı kaynaklardan görüldüğü üzere Kur'an-1 Kerim'den ayetler ve hadislerin yer aldığı madalyonların üzerinde artık SSCB'nin altın renkli beş köşeli kızıl yıldızı yer almıştır. 21 Ocak 1924 yılında SSCB'nin kurucusu Vladimir İliç Ulyanov'un (Lenin) vefatının ertesi sabahı 22 Ocak tarihinde "İsmailiye Sarayı"na Lenin'in adı verilmiş, ancak halk arasında bina "İsmailiye" olarak kalmış ve günümüze kadar da bilime, eğitime hizmet etmiştir. 1924 yılından sonra Azerbaycan Çalışma ve Araştırma Derneği, Türk Kültür Sarayı olarak faaliyete geçen bina SSCB Bilimler Akademisi Transkafkasya Şubesinin Azerbaycan Bölümü olarak kullanılmıştır. Bina 1945 yılından sonra Azerbaycan SSCB Ulusal Bilimler Akademisi olarak değiştirilmiştir. Şu an bina, Azerbaycan Ulusal Bilimler Akademisi Başkanlık Binası olarak kullanılmaktadır. Bu binanın toplantı salonunda sık sık bilimsel konferanslar, edebi tartışmalar yapılmıştır. Maksim Gorki, Vladimir Mayakovsky, Nazım Hikmet gibi yazarlar bu binanın toplantı salonunda okurlarıyla buluşmuştur (URL-1, 2021).

\section{İsmailiye Sarayı'nın Cephe Tasarımında Sembolik Etkilerinin İncelenmesi}

İnşası 1913 yılında tamamlanmış olan bina 1918 Mart Soykırımı sırasında Ermeniler tarafından yağmalanmış ve yakılmıştır. 1920 yılında Azerbaycan'da Sovyet Sosyalist Cumhuriyetler Birliği’nin kurulmasından sonra İsmailiye Sarayı'nın yıkımına karar verilmiş, ancak yerel halkın binanın önüne toplanarak itiraz etmesi nedeniyle restore edilmesine karar verilmiştir.

Ermeni mimar Vartan Sarkisov tarafından restore edilen binanın genel planında değişiklik yapılmasa da cephe tasarımında bazı değişiklikler yapılmıştır. Restorasyon sırasında binanın cephe tasarımında "siyasi” ve "dini” içerikli değişiklikler yapılmıştır. Ayrıca Gotik dönem mimarisinin çıkış yaptığı coğrafyadan uzakta yapılmış bir yapıt olmasına rağmen gotik mimariye ait cephe unsurlarının da sembolik anlamda kullanımları yapılmıştır.

Siyasi içerikli değişikliklerden biri yapının inşası sırasında cephesinde Kur'an-1 Kerim'den ayetler ve hadislerin yer aldığ 1 madalyonlarda yapılmıştır. Bu madalyonlar 
kaldırılarak SSCB'nin beş köşeli kızıl zemin üzerinde sarı çizgilerle oluşturulmuş yıldız kullanılmıştır. (URL-2, 2021). İsmailiye Sarayı'nın yangından önceki; 1913 yılında yapılmış ilk halinde yapının ön cephesinde bulunan madalyonlar üzerinde Kur'an-1 Kerim'den ayetler ve hadislerin yer aldığ restorasyon sırasında bu madalyonların üzerine SSCB'nin sembollerinden olan beş köşeli kızıl yıldızı eklemiştir (URL-2, 2021).

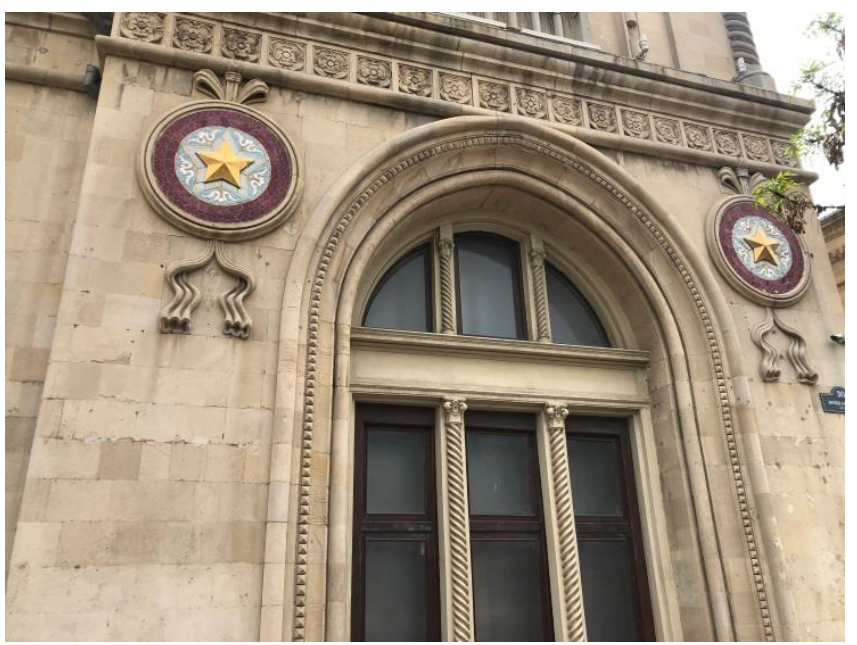

Şekil 3: Restorasyon sonrası İsmailiye Sarayı cephesinde SSCB'nin beş köşeli kızıl yıldızı (2. Yazar fotoğraf arşivi, 2021).

Birçok kuramcı, çeşitli dönemlerde ortaya çıkan şekillerin toplumlar üzerinde egemen olan politikanın bir uzantısı olduğunu savunmaktadır. Örneğin, kare demokrasiye işaret ederken, piramit oligarşiye ya da merkezi plan merkezi idareye işaret etmektedir (Alodall, 2015, s. 44).

Beşköşeli kızıl yıldızdan yola çıkıldığında; her yerde aynı yıldızı gören insanlar artık bu yıldızı kendi simgeleri olarak kabul etmeye başlamış, bu yıldızı ve benzeri Sovyet simgelerini görmek insanlar için normal bir hal almıştır. Okullarda, idari binalarda, televizyon kanallarında, sokaklarda, hemen her yerde aynı sembolleri gören, o dönemlerde yaşamış insanlar arasında hala Sovyetler'in etkisinden çıkamayanlar bulunmaktadır.
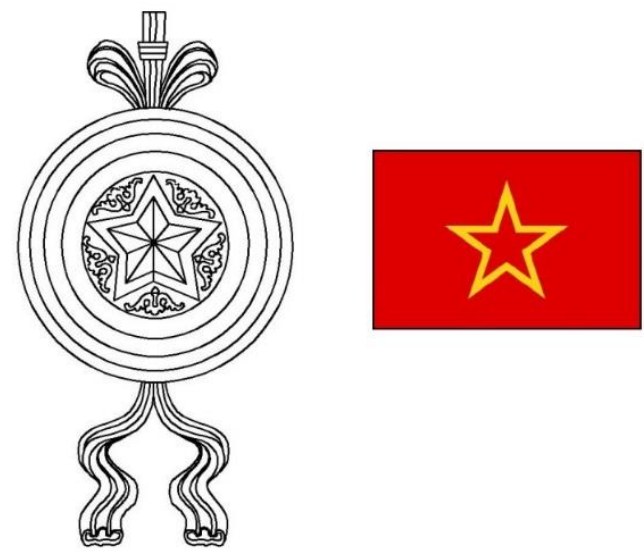

Çizim 1: İsmailiye Sarayı cephesinde restorasyon sonrası üzerinde SSCB kızıl yıldızı eklenmiş madalyon ve SSCB Kızıl Ordu'nun bayrağı görseli (Çizim: Yazarlar tarafından oluşturulmuştur). Resim kaynak: (URL-4, 2021).

Kızıl yıldız, eski Roma savaş tanrısı olarak Mars'tan sonra yaygın olarak bilinen Mars'ın yıldızı olarak anılmıştır. Mars beş köşeli yıldız önce Rus İmparatorluk ordusunda, ardından Sovyet Sosyalist Cumhuriyetler Birliğinde kullanılmıştır (URL-3, 2021). 
Sonradan buna anlam yüklemeye çalıșan Sovyetler yıldızı şöyle anlamlandırmıștır: Sosyalizm ve komünizmin simgesi olan bu yıldızın beş köşesi emekçilerin beş parmağını ve beş kıtayı temsil etmektedir. Az bilinen anlamlarından biri de yıldızın beş köşesinin toplumu sosyalizme taşıması ve onu savunacak beş farklı sosyal grubun temsil etmesidir. Bu grup herhangi bir sırası olmadan şöyledir: gençlik, sanayi işçileri, çiftçiler, ordu ve entelijansiya (komünizme ulaşmak için fikir üretmesi gereken sınıf). Kızıl yıldız 1922 yılından SSCB'nin resmi ordusu olan Kızıl Ordu'nun bayrağı olarak bilinmektedir (URL-4, 2021).Yapılan bu uygulamada, medeniyet tarihi boyunca idari ve siyasi erki elinde tutan tüm devletlerin diğer devletlere üstünlüğünü ve gücünü gösterme çabasının bir benzeri izlenmektedir. Bu çabada araç olarak da mimari yapının cephesinde sembol kullanımı tercih edilmiştir.

Siyasi içerikli bir diğer değişim yapının cephesindeki isimlik kısmında olmuştur. Yapının restorasyonu sonrasında Azerbaycan için önemli bir yeri olan İsmailiye Sarayı'nın cephe tasarımında sadece süslemeler üzerinden değişiklikler değil, aynı zamanda yapının ismi üzerinden de değişiklikler yapılmıştır. Yapımı 1913 yılında tamamlanmış binanın ön cephesinde bulunan "İsmailiye Sarayı" yazısı restorasyon sonrasında binanın cephe tasarımına eklenmemiş ve binanın ismi değiştirilmiştir. Ardından saray yukarıdaki bölümlerde de belirtildiği gibi farklı isimlerle farklı kurumlar için faaliyet göstermiştir. En son 1945 y1lından 1991'e kadar Azerbaycan SSCB Ulusal Bilimler Akademisi olarak kullanılan bina, 1991 yılından günümüze kadar ise Azerbaycan Ulusal Bilimler Akademisi Başkanlık Binası olarak faaliyet göstermektedir (URL-1, 2021). Mart soykırımı sırasında binanın Ermeniler tarafından ateşe verilmesi sonucunda binada çıkan yangın sırasında İsmailiye Sarayı'nın bütün arşivleri yanarak yok olmuştur. Bu sebepten, binayla ilgili bahsedilen İsmailiye Sarayı yazısının yer aldığı cephe görüntüsü de günümüze kadar ulaşamamıştır.

Aşağıda gösterilen resimlerde de binanın 1991 yılına kadar ve 1991 yılından sonraki isminin yazıldığı cephe görüntüleri görülmektedir.

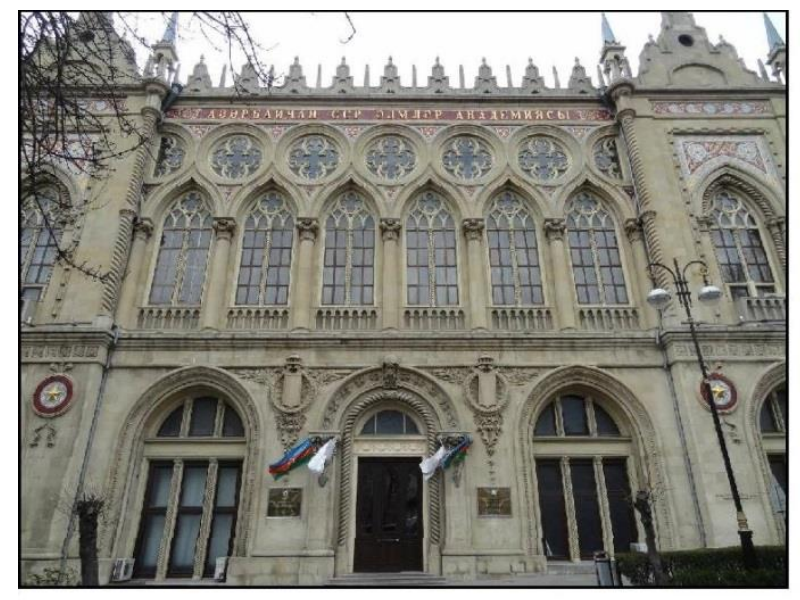

şekil a

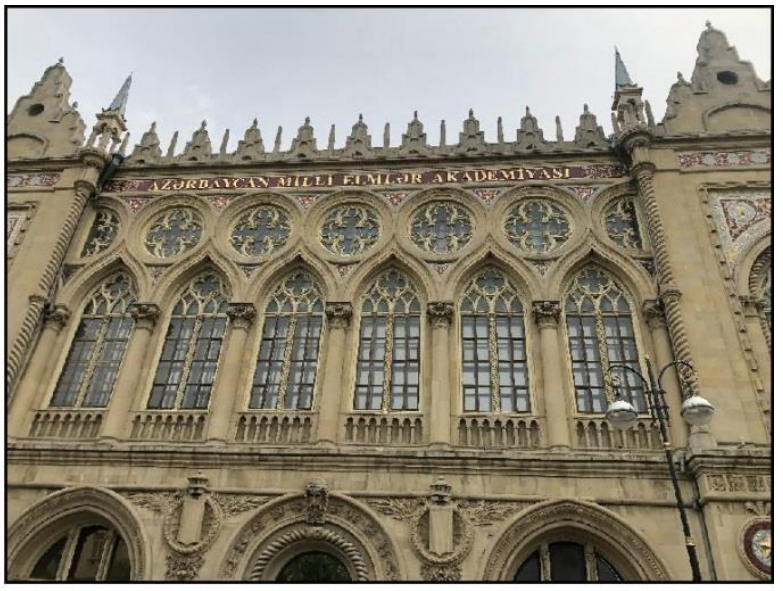

şekil b

Şekil 4: Şekil a'daki cephe görünüşünde yapının 1991 yılına kadarki kiril alfabesinde yazılmış olan ismi (Азербайчан ССР Элмләр Академиясы), şekil b'de ise yapının 1991 yılından sonraki ismi (Azərbaycan Ulusal Bilimler Akademisi).Şekil a kaynak: (URL-6).Şekil b kaynak: 2. yazar (2021).

Yapının cephe tasarımında yapılmış dini içerikli değişiklik mimar Plosko’nun tasarlamış olduğu kubbelerin restorasyon sonrasında olmaması ve kubbelerin yerine binanın esas siluet motifleri rolündeki piramit şekilli frontonlara benzer tasarımın uygulanmasıdır. Plosko'nun tasarımına göre ve İsmailiye Sarayı'nın mimari kompozisyonuna uygun olarak, rizalitlerin üzerine farklı örtülü kubbelere sahip yuvarlak kemerler yerleştirilmiştir. Binanın 1918 'de Ermeniler tarafından vurularak ateşe verildiği sırada bu kemerlerin yıkıldığına dair kesin bir bilgi elde edilememiştir. Ancak bina yangın zamanı çok ciddi hasar görmüştür (Fetullayev-Figarov, 2013, s. 28). Aşağıdaki çizimlerden de yapının Sovyetler döneminde 
geçirmiş olduğu restorasyon sürecinde cephesinde yapılmış dini içerikli değişikliği görmek mümkündür.

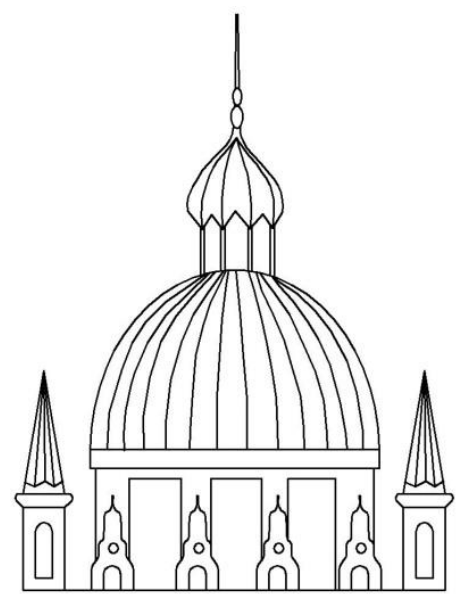

çizim a

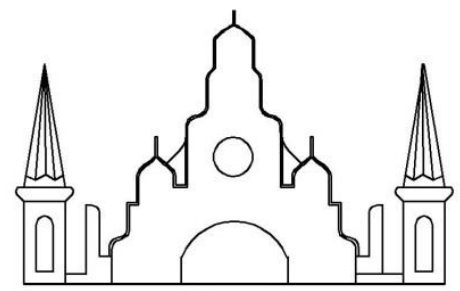

çizim b

Çizim 2: Çizim a'daki kubbe şekilli kemerler Plosko'nun projesine göre çizilmiş, ancak restorasyon sonrası çizim b'deki piramit şekilli tasarım yapılmıştır (Çizim: yazarlar tarafından oluşturulmuştur).

Gotik dönem, Orta çağın ardından gelmiş ve Rönesans'ı başlatan akımdır. Tüm sanat dallarında görülmekle birlikte Gotik, bir mimarlık üslubu olarak daha çok eserin üretildiği ve hatta gotik yapıların taklitlerinin de yapıldığı yaygın bir alanı kapsamaktadır. Yüksek orta çağı içine alan Gotik devir, papalık ve krallık arasında bir kudret göstergesi olarak karşımıza çıkmaktadır (Yıldız, 2015). Bir sanat anlayışı, üslubu veya stili olarak bilinen Gotik Sanatın da ortaya çıktığı dönemden bu yana, kendisinden sonra gelen sanat üsluplarını ve akımlarını etkilediği İsmailiye Sarayı cephe tasarımında da görülmektedir.

1913 yılında yapımı tamamlanmış binanın ikinci kat cephesinde bulunan güle benzer süslemenin yerini restorasyon sonrasında daha gösterişli bir güle benzer süsleme almıştır. Bu tür süslemeler genellikle Gotik mimaride s1k görülmektedir.

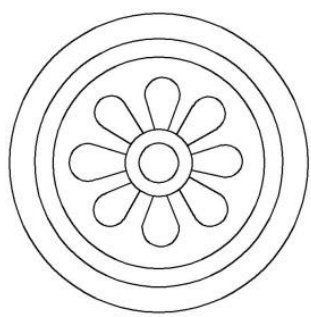

çizim a

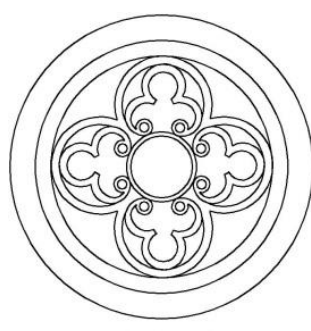

çizim b

Çizim 3: Çizim a'ya göre daha gösterişli olan çizim b’deki güle benzer süsleme restorasyon sonrasında binanın ikinci kat cephe tasarımına eklenmiştir (Çizim: Yazarlar tarafindan oluşturulmuştur).

Özellikle mimaride 12. yy. başlarında ortaya çıkmış olan Gotik mimarinin genel özelliklerinden; sivri kemerlerin, gül pencerelerin kullanılması, pencereler ve açıklıkların ön plana çıkarılması gibi bazı özellikleri İsmailiye Sarayı cephesinde de görülmektedir (Gülcan, 2019, s. 2231). Bu örneği aşağıdaki çizimde ve görselde de görmek mümkündür. 

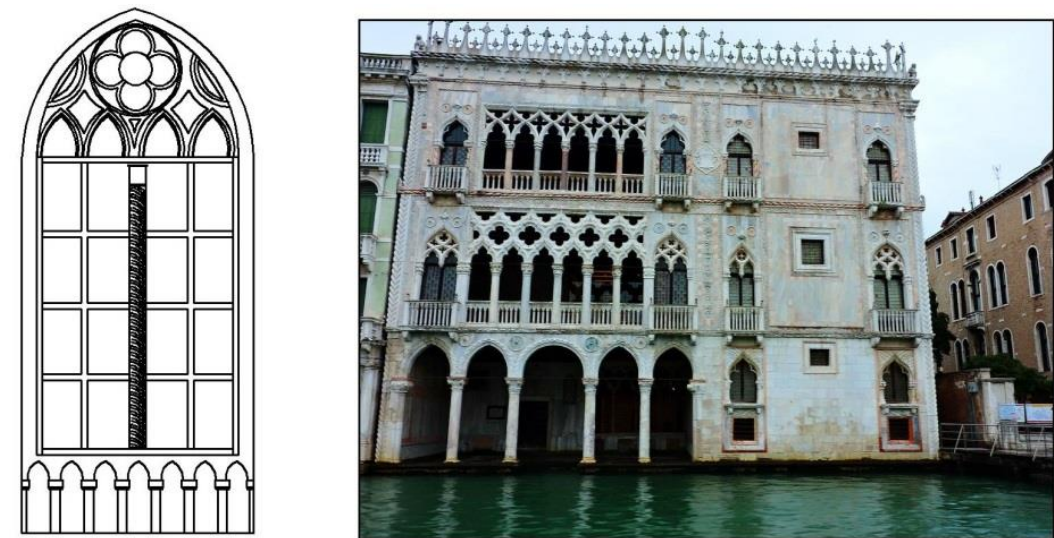

Çizim 4: İsmailiye Sarayının ön cephesindeki pencerelerden birinin çizimi ve Venedik'de bulunan Gotik tarzda yapılmış "Contarini Della Figure” Sarayı görseli (Çizim: Yazarlar tarafından oluşturulmuştur).Resim kaynak: (URL-5, 2021).

Sarayın cephesinde yapılmış Gotik mimari örneklerinden biri de yapının esas silüet motifleri rolündeki piramit şekilli frontonlara benzer tasarımlardır. Bu tür tasarımları birçok Gotik mimari örneklerinde görmek mümkündür. Gotik mimarinin, binaların uzunlamasına büyüme eğiliminde olması özelliği bu motifler üzerinde yansıtılmıştır (Gülcan, 2019, s. 2232)

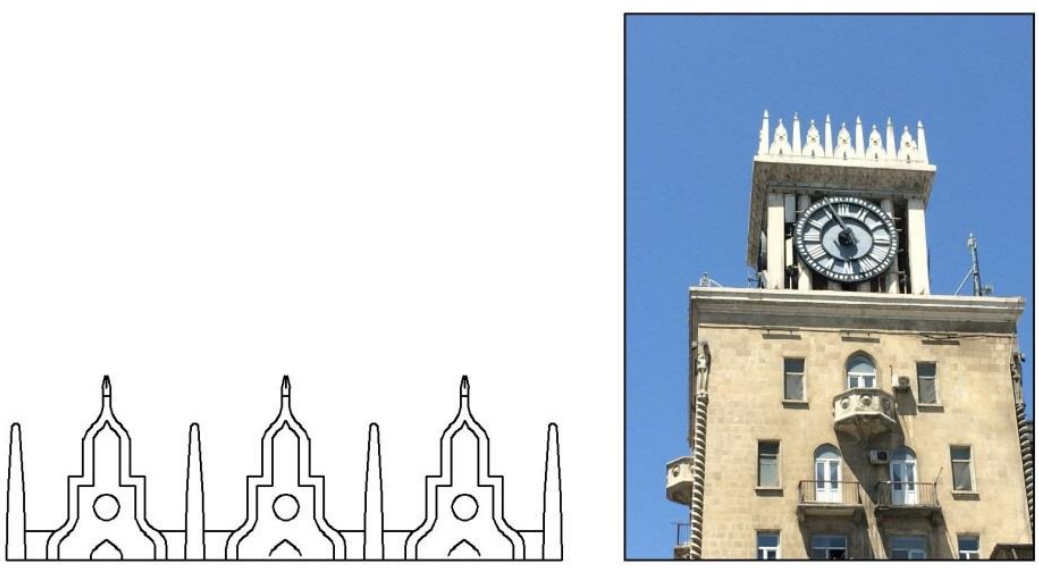

Çizim 5: İsmailiye Sarayı cephesinin esas siluet motiflerinden olan frontonlara benzer tasarımın çizimi ve Bakü’de bulunan Gotik tarzda yapılmış "Saatli Bina“" görseli (Çizim ve resim: 2. Yazarın arşividir, 2021).

\section{Bulgular ve Sonuç}

Yapılan çalışmada sembolizm kavramı ve Bakü'de bulunan İsmailiye Sarayı'nın 1923 yılında geçirmiş olduğu restorasyon sırasında cephe tasarımında kullanılmış sembollerin etkileri araştırılmıştır. Yapının geçirmiş olduğu restorasyon sürecinde cephe tasarımında dini, siyasi içerikli, Gotik mimari üzerinden yapılmış değişiklikleri ve yapının cephesinde yapılan isim değişiklikleri çizimler ve resimler eşliğinde incelenmiştir.

Sovyetler döneminde yapılmış restorasyon sırasında SSCB'nin, beş köşeli kızıl yıldızı, mimar Plosko'nun projesine göre tasarlanmış kubbelerin yerine piramit şekilli tasarımları eklemiş olduğunu, aynı zamanda Gotik mimari etkisini ve isim değişikliğini yapının cephe tasarımında görmek mümkündür. Yapının en önemli bölümlerinden olan, ilk kez bakıldığında bile yapı hakkında insanda izlenimler uyandıran cephe tasarımında kullanılan semboller her zaman form aracılığıyla insanlara aktarılmıştır.

Çalışmada incelenmiş olan İsmailiye Sarayı üzerinde SSCB'nin formlar, semboller aracılığıyla kendi izlerini bırakmaya çalışması görülmektedir. Bu sembollere bakıldığında bu yapıların Sovyetler Birliği zamanında yapılmış olduğunu sanılarak günümüzde de Sovyetler' in ülkeye faydalı işler gördüğü düşünülebilmektedir. 
Mimar Plosko'nun projesine göre tasarlanmış kubbelerin restorasyon sonrasında olmaması da cepheye sembolizm alt yapısında yapılmış önemli müdehalelerdendir.

İsmail'in anısına Müslüman Hayır Cemiyeti'nin kullanımı için yapılmış olan binanın restorasyon sonrasında isim ve kullanım değişikliğinde de Sovyetler Birliği'nin kendi izlerini geleceğe bırakma çabaları açıkça görülmektedir.

Çalışmanın sonucunda incelemiş olduğumuz yapının restorasyon sırasında cephesinde yapılan değişiklikler sayesinde, SSCB'nin hakimiyyette olduğu 71 yıl müddetinde birçok yapılara uygulamış olduğu sembollerin aracılığıyla kendisini hafizalara kaydetmiş olduğu görülmektedir.

İsmailiye Sarayı gibi değişime uğramış yapılar hakkında daha çok bilgi, belge araştırılmalı ve geleceğe, yeni nesillere gerekli bilgiler aktarılmalıdır.

1923 yılında geçirmiş olduğu geçirmiş olduğu restorasyon sonrasında cephe tasarımında bazı değişiklikler yapılmış İsmailiye Sarayı örneğinde görüldügü gibi; cephe tasarımlarında sembollerin kullanımının her açıdan diğer alanlara göre daha etkili olduğu sonucuna gelinmiştir.

Sonuç olarak; 19. yüzyılın sonlarında ortaya çıkmış sembolizmin aslında göz ardı edilemeyecek derecede bir gerçek olduğu görülmektedir. Yapılan çalışmanın sonucunda da İsmailiye Sarayı'nın cephe tasarımında sembolizmin etkileri açıkça görülmüştür.

\section{Kaynakça}

Alodalı, A., (2015). Mimarlıkta sembolizm, Kutsal'ın mimariyle buluşması ve Kabe örneği. Yüksek Lisans Tezi, Fatih Sultan Mehmet Üniversitesi.

Aydeniz, H., (2011). Dini semboller, sembolün anlam kaybı ve etkilerine gelenekselci bir yaklaşım( Rene Gueonon örneği). Ekev, 48, 75-90.

Dianat, S., (2015). Mimarlıkta sembolizm ve simgesel anlamı. Yıldız Teknik Üniversitesi.

Fetullayev-Figarov, Ş., (2013). Memar I.K.Ploşko-"İsmailiyyə"nin müəllifi. Bakü: Ami.

Gülcan, N., (2019). Ortaçă̆ Avrupa'sında skolastik felsefe ve gotik mimari. Turkish Studies Social Sciences, 14, 2225-2234.

Hasanl1, K., (2021). Mirzabeyov'un binası, Bakü.

Yıldı,, Ş., (2015). Gotik dönem mimarisi ve dönem giysi tasarımlarına etkisi, International Journal of Science Culture and Sport (IntJSCS) August 2015 : Special Issue 4 ISSN : 21481148 Doi : 10.14486/IJSCS386

Url-1. Ismailiye Sarayl. (E. T: 02.03.2021). https://tr.wikipedia.org/wiki/\%C4\%B0smailiye_Saray\%C4\%B1

Url-2. Xəsis milyonçu Musa Nağıyev və Bakının "qızıl binası". (E. T: 18.05.2021). https://www.kultura.az/az/article/2654/

Url-3. Muzey Pobedı. Sovyetler Birliği Kahramanı Madalyası Kızıl Yıldız. (E. T: 19.04.2021). https://victorymuseum.ru/about/museum-collection/numismatics/medal-zolotayazvezda-geroya-sovetskogo-soyuza/

Url-4. Rusya Federasyonu Savunma Bakanlığı. Kızıl yıldız-Kızıl Ordu'nun sembolü. (E. T: 19.04.2021).

https://encyclopedia.mil.ru/encyclopedia/history/more.htm?id=12175625@cmsArticle

Url-5. Contarini Della Figure side facade. (E. T: 10.05.2021). https://www.google.com/imgres?imgurl=https\%3A\%2F\%2Fhopa.am\%2Fuploads\%2F cms\%2Fimages\%2F1582707266_venice_cadoro.jpg\&imgrefurl=https\%3A\%2F\%2Fh opa.am\%2Fblog\%2FVenice---the-miracle-at-the-

lagoon\&tbnid=NNmPEKZuy4DXJM\&vet=12ahUKEwi9oIPJh7_wAhXIwoUKHXPw DgwQMygTe 
URL-6. UBP-Uşaq birlik portalı. История двориа Исмаилия. (Е. T: 29.05.2021). https://portal.azertag.az/ru/node/4218 